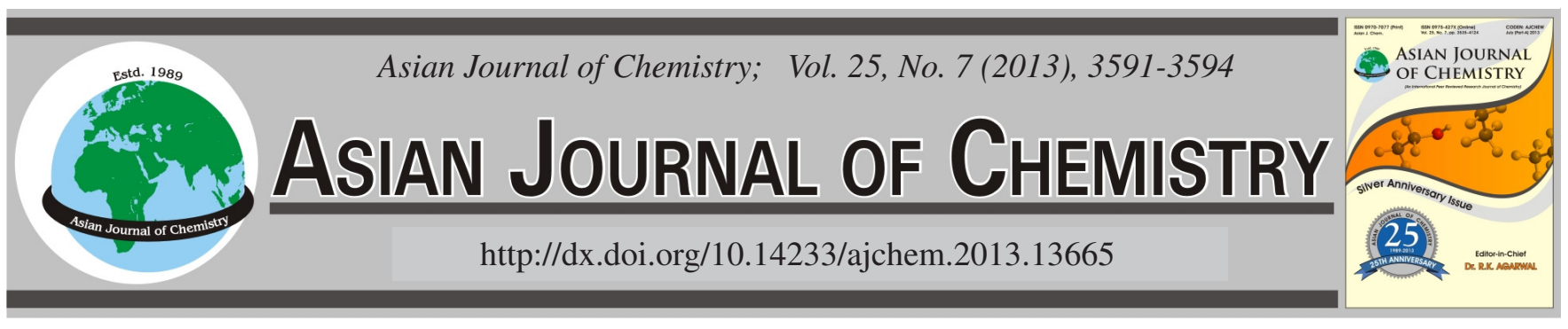

\title{
Sphingomonas-Paucimobilis of Sodium Alginate Fossilization Bacillus subtilis Pellet to Chrome of Mine Wastewater
}

\author{
Jun-JiNG GuO* and WEN-BIN CHEN
}

Department of Chemical Engineering, Huaihai Institute of Technology, Lianyungang 222005, P.R. China

*Corresponding author: Tel: +86 130 56050082; E-mail: lygcwb11@163.com

\begin{abstract}
This study use purely bacteria on suitable condition, eliminate other bacteria come in life-form bacteria. Through the orthogonal experiment obtains the optimum condition of sodium alginate fossilization Bacillus subtilis pellet to chrome adsorption and discusses the influence of single factor to the sodium alginate fossilization Bacillus subtilis pellet to chrome adsorption, including the time, the temperature, $\mathrm{pH}$, the initial adsorbent density, the speed of the shaker, the absorbent which the different periods of growth bacterium doses, coexistent ion, desorption. From the research, we know the maximum adsorption rate to chrome is $c a .80 \%$. Dynamics research indicated that in the several methods of the Sphingomonas-paucimobilis of chrome, the methods of embedded micro-organisms embodies much advantages, as operating easily, effecting clearly, less pollution, costing low, etc.
\end{abstract}

Key Words: Mine wastewater, Sodium alginate, Fossilization, Bacillus subtilus, Chrome.

\section{INTRODUCTION}

Metal mine development of mining, dressing and smelting will discharge heavy metals into the environment ${ }^{1,2}$. The weathering of solid waste could lead to leaching and releasing heavy metals, particularly in the process of exploiting and utilizing the lead-zinc, mercury, -used thallium ore, the lead, zinc, arsenic, thallium and associated components, such as cadmium, chromium, copper in tailings waste rocks will enter into the soil and accumulate after washing and leaching by the surface water and rainwater. The potential impact of hazards and threats are more serious than apparent effect, once the formation of some toxic elements, the remediation will be very difficult, short-term can not be effective, the disaster caused by it is sudden. Research found that hexavalent chromium compounds have carcinogenic effects in vivo, it will also cause many other health problems.

Chromium wastewater treatment methods are generally physical and chemical methods, such as neutralization and precipitation, coagulation and precipitation, adsorption method, ion exchange, membrane separation, etc. ${ }^{3,4}$. In recent years, use biosorption method to conduct wastewater containing heavy metal aroused the attention of environmental workers. It has the advantages of high efficiency, selectivity, adsorption capacity, etc. and will not cause secondary pollution and the cost of wastewater treatment is low. Biosorbent primarily are fungus, starch, fiber and algae. At present, the development trend of bio-absorption study is to look for an adsorbent with a high selectivity which can adsorb a certain metal, with rich sources, low cost and special construction of cells of microbiological, it has a great affinity, selective removal of heavy metals and high efficiency in the process of removing heavy mental. Use yeast, bacteria, algae and other biological materials to accumulate heavy metals is one of the current research focuses ${ }^{5,6}$. As the deep research of biosorption, many scholars ${ }^{5,6}$ found that dead cells or "semi-alive"; "half full"; state of the cells can adsorb metal in an equal efficiency or even higher efficiency, so as to solve the problem brought by the toxic effects of high concentration of metal ions which lead to the limit of using it. In general, in areas affected by heavy metals can select the microorganisms resisting contamination of heavy metals, these resistant organisms have a potential adsorption to heavy metal, they are the great source of heavy metals adsorbent and precipitating agent ${ }^{7}$. But the direct use of the free cells of microorganisms has many drawbacks, because of its density, low intensity, small diameter, easily washed away by water, utilization is low and the secondary pollution caused by the medium, it is difficult to put them into actual production directly. Therefore, we use agar, gelatin, sodium alginate and other carriers ${ }^{8,9}$ to fasten them and then put them into application. Among them, sodium alginate is used to immobilized microbial cells, it has the 
advantages that easy to mold, low microbial toxicity and higher density of immobilized cells, it is also a most widely used and studied fasten method ${ }^{10}$.

From the above reports we can know that the species of microorganisms used for preventing and curing heavy metals which taking advantages of marine microorganism resources are small, while the marine microorganisms are resistant to harsh environments. So it is very significant to screen the HIV strains resisting heavy metals from marine microorganisms and treat the pollution of heavy metal wastewater in mines. In this paper we study the sphingosine aeromonas sphingom onas strainRB2256 selected from marine sediment. Use them to adsorb chromium after they are fastened by the sodium alginate, reach the purpose that conducting the refining experiment which including the optimum adsorption condition's effect on mining wastewater polluted by heavy metals through orthogonal experiments, maintaining the ecological balance of aquatics and can make the polluted, degraded ecological environment bioremediation.

\section{EXPERIMENTAL}

Major equipment and reagents: WFJ-7200 Spectrophotometer (Unico (Shanghai) Instruments Co., Ltd.); TDL-4 flying Pigeon series centrifuge (Shanghai Anting Scientific Instrument Factory); Sw-CJ-1D type sterile console (Suzhou Purification Equipment Co., Ltd.); pHSJ-5-type laboratory pH meter (Shanghai Instrument Co., Ltd. established); SHP-180 Biochemical Incubator (Shanghai Lei magnetic Instrument Factory); HZQ-QX-type Full Temperature Oscillator (Shanghai Experimental Instrument Factory ); Vertical Pressure Steam Sterilizer (Harbin East Union Electronic Technology Co., Ltd.). Calcium chloride solution: $20 \mathrm{mg} / \mathrm{L}$, weighed $20 \mathrm{~g}$ of calcium chloride dissolved in water, moved to $1000 \mathrm{~mL}$ capacity of the bottle, diluted to the standard line, shaking.

Preparation of alginate immobilized Sphingomonas ball cells: (1) preparation of $2 \%$ (mass volume concentration) of sodium alginate-Sphingomonas cell mixture (1 g sodium alginate add into the $50 \mathrm{~mL}$ prepared bacteria liquids); (2) draw a syringe of sodium alginate-Sphingomonas cell mixture, gradually adding into the $\mathrm{CaCl}_{2}$ solution, aging $4 \mathrm{~h}$; (3) dump the $\mathrm{CaCl}_{2}$ solution, wash alginate immobilized Sphingomonas cells with distilled water at least 3 times (with washing solution does not contain $\mathrm{Ca}^{2+}$ ).

Conditional experiments and results analysis of sodium alginate immobilized Sphingomonas cells's (living) degradation of copper mine wastewater: In the experiment, we use the mine wastewater in a tungsten mine in Hunan as the treatment samples, the initial concentration of chromium in the mine waste water samples is $2.16 \mathrm{mg} / \mathrm{L}$.

Determination of chromium: In the acidic solution, hexavalent chromium reacted with the diphenyl hydrazine produce purple compound, for spectrophotometry in the wavelength $540 \mathrm{~nm}$.

Orthogonal group: There are four factors in the experimental design: temperature, initial concentration, $\mathrm{pH}$ and time, they were set to A, B, C, D, each factor has four levels, use the orthogonal table in all four levels of 4 factors to divide the experiment into 16 groups, among them $\mathrm{A} 1: 37^{\circ} \mathrm{C}, \mathrm{A} 2: 30^{\circ} \mathrm{C}$,
A3: $20^{\circ} \mathrm{C}, \mathrm{A} 4: 10^{\circ} \mathrm{C}$; B1: $0.9 \mathrm{~g} / \mathrm{L}, \mathrm{B} 2: 1.0 \mathrm{~g} / \mathrm{L}, \mathrm{B} 3: 1.1 \mathrm{~g} / \mathrm{L}$, B4: $1.2 \mathrm{~g} / \mathrm{L} ; \mathrm{C} 1: \mathrm{pH}=4, \mathrm{C} 2: \mathrm{pH}=5, \mathrm{C} 3: \mathrm{pH}=6, \mathrm{C} 4: \mathrm{pH}=7$; D1: 90 min, D2: 100 min, D3: 110 min, D4: 120 min.

Test steps: Get tested mine waste water, add nanomaterials into it, place it in the A factor in the shaker at different temperatures, the oscillation of the different D factor of time, after shaking, filter it, then measure the lead content in mine waste.

\section{RESULTS AND DISCUSSION}

\section{Orthogonal experiment}

Orthogonal experiment scheme: The orthogonal test use 4 factors with 4 levels to divide the experiment into 16 groups, the 4 factors were divided into temperature, ball quality, $\mathrm{pH}$ and time, corresponding to A, B, C, D, each element corresponding 4 levels.

Among them, $\mathrm{A}_{1}: 37{ }^{\circ} \mathrm{C}, \mathrm{A}_{2}: 30^{\circ} \mathrm{C}, \mathrm{A}_{3}: 20{ }^{\circ} \mathrm{C}, \mathrm{A}_{4}: 10{ }^{\circ} \mathrm{C}$; $\mathrm{B}_{1}: 0.9 \mathrm{~g}, \mathrm{~B}_{2}: 1.0 \mathrm{~g}, \mathrm{~B}_{3}: 1.1 \mathrm{~g}, \mathrm{~B}_{4}: 1.2 \mathrm{~g} ; \mathrm{C}_{1}: \mathrm{pH}=4, \mathrm{C}_{2}: \mathrm{pH}=5$, $\mathrm{C}_{3}: \mathrm{pH}=6, \mathrm{C}_{4}: \mathrm{pH}=7 ; \mathrm{D}_{1}: 90 \mathrm{~min}, \mathrm{D}_{2}: 100 \mathrm{~min}, \mathrm{D}_{3}: 110 \mathrm{~min}$, $\mathrm{D}_{4}: 120 \mathrm{~min}$.

Regulate different $\mathrm{pH}$ ( $\mathrm{C}$ factor) with mine drainage water samples, add different quality of alginate immobilized Sphingomonas cells ball (B factor), place in different temperatures (A factor) of the shaking, shake at different time (D factor), after shaking, filter, test the content of hexavalent chromium in mine wastewater.

Calculate the adsorption capacity and adsorption rate of adsorbent through measuring concentration of heavy metals in mine wastewater, the data was shown in Table- 1 .

Range analysis of orthogonal: Calculate the adsorption capacity and adsorption rate of adsorbent through measuring concentration of hexavalent chromium in mine wastewater, as well as obtain the optimal combination by the range analysis, as shown in Tables 1 and 2.

\section{Study of microbial adsorption mechanism of heavy metals}

SEM and EDS: Make a comparison between Figs. 1 and 2 , it is obvious that alginate immobilized Sphingomonas cells (live) adsorb a layer of material in the surface, it adsorb a layer of silver white in the surface of Fig. 2, a kind of slightly blue crystal. Combine with EDS, it can be further identified that sodium alginate immobilized Sphingomonas cells absorbed $\mathrm{Cr}^{6+}$ successfully through the energy spectrum.

Infrared spectroscopy: The IR spectra analysis shows: the absorption peak of sodium alginate immobilized Sphingomonas cells and $\mathrm{Cr}^{6+}$ at $3435,1634 \mathrm{~cm}^{-1}$. Compared with the sodium alginate immobilized Sphingomonas cells which are not take part in react, after reacting with the $\mathrm{Cr}^{6+}$, the hydroxyl-OH, carboxylic and the absorption peak caused by the vibration of $-\mathrm{CH}_{2}$ - has changed significantly, the peak of hydroxyl and the ion peak of carboxylic acid become significantly wider, while the absorption peak caused by the vibration of $-\mathrm{CH}_{2-}$ decreased largely, it indicates that $\mathrm{Cr}^{6+}$ alginate immobilized Sphingomonas cells of the hydroxyl$\mathrm{OH},-\mathrm{CH}_{2}$ - and the carboxylic acid ion have occurred to react.

\section{Conclusion}

From the experiments that sodium alginate immobilized Sphingomonas cells adsorb chromium ion in mine wastewater, 


\begin{tabular}{|c|c|c|c|c|c|c|c|c|}
\hline \multicolumn{9}{|c|}{$\begin{array}{c}\text { TABLE- } 1 \\
\text { THE ORTHOQONAL EXPERIMENTS OF Bacillus subtilis SODIUM ALGINATE IMMOBILIZED } \\
\text { LIVING ORTHOGONAL CHROMIUM ION ADSORPTION (ADSORPTION RATE) }\end{array}$} \\
\hline Test No. & A & B & $\mathrm{C}$ & $\mathrm{D}$ & \multicolumn{2}{|c|}{ Adsorption rate (\%) } & \multicolumn{2}{|c|}{ Mean } \\
\hline 1 & 37 & 0.9 & 4 & 90 & 60.75 & 61.72 & 62.51 & 61.66 \\
\hline 2 & 37 & 1.0 & 5 & 100 & 71.33 & 70.3 & 70.68 & 70.77 \\
\hline 3 & 37 & 1.1 & 6 & 110 & 79.29 & 78.38 & 76.99 & 78.22 \\
\hline 4 & 37 & 1.2 & 7 & 120 & 82.57 & 81.52 & 81.94 & 82.01 \\
\hline 5 & 30 & 0.9 & 5 & 110 & 71.77 & 71.74 & 71.74 & 71.75 \\
\hline 6 & 30 & 1.0 & 4 & 120 & 59.23 & 57.57 & 58.58 & 58.46 \\
\hline 7 & 30 & 1.1 & 7 & 90 & 79.89 & 76.05 & 77.22 & 77.72 \\
\hline 8 & 30 & 1.2 & 6 & 100 & 75.27 & 76.19 & 74.26 & 75.24 \\
\hline 9 & 25 & 0.9 & 6 & 120 & 77.65 & 78.62 & 79.53 & 78.6 \\
\hline 10 & 25 & 1.0 & 7 & 110 & 68.44 & 68.38 & 68.26 & 68.36 \\
\hline 11 & 25 & 1.1 & 4 & 100 & 55.85 & 55.64 & 55.49 & 55.66 \\
\hline 12 & 25 & 1.2 & 5 & 90 & 69.17 & 69.32 & 69.41 & 69.3 \\
\hline 13 & 20 & 0.9 & 7 & 110 & 70.03 & 70.3 & 70.51 & 70.28 \\
\hline 14 & 20 & 1.0 & 6 & 90 & 78.52 & 78.57 & 78.65 & 78.58 \\
\hline 15 & 20 & 1.1 & 5 & 120 & 66.39 & 66.4 & 66.47 & 66.42 \\
\hline 16 & 20 & 1.2 & 4 & 100 & 53.81 & 53.75 & 53.66 & 53.74 \\
\hline Adsorption rate $\mathrm{K} 1$ & 292.66 & 282.29 & 229.52 & 287.26 & - & - & - & - \\
\hline K2 & 283.17 & 276.17 & 278.24 & 255.41 & - & - & - & - \\
\hline K3 & 271.92 & 278.02 & 310.64 & 288.61 & - & - & - & - \\
\hline K4 & 269.02 & 280.29 & 298.37 & 285.49 & - & - & - & - \\
\hline k1 & 73.165 & 70.0725 & 57.38 & 71.815 & - & - & - & - \\
\hline k2 & 70.7925 & 69.0425 & 69.56 & 63.8525 & - & - & - & - \\
\hline k3 & 67.98 & 69.505 & 77.66 & 72.1525 & - & - & - & - \\
\hline $\mathrm{k} 4$ & 67.255 & 70.5725 & 74.5925 & 71.3725 & - & - & - & - \\
\hline Range $\mathrm{R}$ & 5.91 & 1.53 & 17.2125 & 7.9625 & - & - & - & - \\
\hline Order of factors & & $\mathrm{C}>\mathrm{I}$ & $>\mathrm{B}$ & & & & & - \\
\hline $\begin{array}{c}\text { Priority level } \\
\text { Excellent combination }\end{array}$ & $\mathrm{A}_{1}$ & ${ }^{\mathrm{B}_{4}} \mathrm{C}_{3}$ & ${ }_{\mathrm{B}_{4}} \mathrm{C}_{3}$ & $\mathrm{D}_{3}$ & - & - & - & $\begin{array}{l}- \\
- \\
\end{array}$ \\
\hline
\end{tabular}

TABLE- 2

ALGINATE IMMOBILIZED Bacillus subtilis in vivo ADSORPTION OF CHROMIUM ION IN THE ORTHOGONAL EXPERIMENT (ADSORPTION)

\begin{tabular}{|c|c|c|c|c|c|c|c|c|}
\hline Test No. & A & B & $\mathrm{C}$ & $\mathrm{D}$ & \multicolumn{3}{|c|}{ Adsorption capacity (mg/g) } & Mean \\
\hline 1 & 37 & 0.9 & 4 & 90 & 4.55625 & 4.629 & 4.68825 & 4.6245 \\
\hline 2 & 37 & 1.0 & 5 & 100 & 5.34975 & 5.2725 & 5.301 & 5.30775 \\
\hline 3 & 37 & 1.1 & 6 & 110 & 5.94675 & 5.8785 & 5.77425 & 5.8665 \\
\hline 4 & 37 & 1.2 & 7 & 120 & 6.19275 & 6.114 & 6.1455 & 6.15075 \\
\hline 5 & 30 & 0.9 & 5 & 110 & 5.38275 & 5.3805 & 5.3805 & 5.38125 \\
\hline 6 & 30 & 1.0 & 4 & 120 & 4.44225 & 4.31775 & 4.3935 & 4.3845 \\
\hline 7 & 30 & 1.1 & 7 & 90 & 5.99175 & 5.70375 & 5.7915 & 5.829 \\
\hline 8 & 30 & 1.2 & 6 & 100 & 5.64525 & 5.71425 & 5.5695 & 5.643 \\
\hline 9 & 25 & 0.9 & 6 & 120 & 5.82375 & 5.8965 & 5.96475 & 5.895 \\
\hline 10 & 25 & 1.0 & 7 & 110 & 5.133 & 5.1285 & 5.1195 & 5.127 \\
\hline 11 & 25 & 1.1 & 4 & 100 & 4.18875 & 4.173 & 4.16175 & 4.1745 \\
\hline 12 & 25 & 1.2 & 5 & 90 & 5.18775 & 5.199 & 5.20575 & 5.1975 \\
\hline 13 & 20 & 0.9 & 7 & 110 & 5.25225 & 5.2725 & 5.28825 & 5.271 \\
\hline 14 & 20 & 1.0 & 6 & 90 & 5.889 & 5.89275 & 5.89875 & 5.8935 \\
\hline 15 & 20 & 1.1 & 5 & 120 & 4.97925 & 4.98 & 4.98525 & 4.9815 \\
\hline 16 & 20 & 1.2 & 4 & 100 & 4.03575 & 4.03125 & 4.0245 & 4.0305 \\
\hline Adsorption capacity K1 & 21.9495 & 21.17175 & 17.214 & 21.5445 & - & - & - & - \\
\hline K2 & 21.23775 & 20.71275 & 20.868 & 19.15575 & - & - & - & - \\
\hline K3 & 20.394 & 20.8515 & 23.298 & 21.64575 & - & - & - & - \\
\hline K4 & 20.1765 & 21.02175 & 22.37775 & 21.41175 & - & - & - & - \\
\hline $\mathrm{k} 1$ & 5.487375 & 5.255437 & 4.3035 & 5.386125 & - & - & - & - \\
\hline $\mathrm{k} 2$ & 5.309437 & 5.178187 & 5.217 & 4.788937 & - & - & - & - \\
\hline k3 & 5.0985 & 5.212875 & 5.8245 & 5.411437 & - & - & - & - \\
\hline $\mathrm{k} 4$ & 5.044125 & 5.292937 & 5.594437 & 5.352937 & - & - & - & - \\
\hline Range R & 0.44325 & 0.11475 & 1.290937 & 0.597187 & - & - & - & - \\
\hline Order of factors & & $C>D$ & $A>B$ & & & & & - \\
\hline $\begin{array}{l}\text { Priority level } \\
\text { Excellent combination }\end{array}$ & $\mathrm{A}_{1}$ & ${ }^{\mathrm{B}_{4}} \mathrm{C}_{3} \mathrm{I}$ & ${ }_{1} \mathrm{~B}_{4}$ & $\mathrm{D}_{2}$ & - & - & - & $\begin{array}{l}- \\
-\end{array}$ \\
\hline
\end{tabular}

Note: The K1, K2, K3, K4 in the table are the individual sum of 4 factors in each level. In the table, $R_{B}>R_{A}>R_{C}>R_{D}$, so the priority order of factors are: $C>D>A>B$; As state above, the excellent combination is: $C_{3} D_{2} A_{1} B_{4}$, that is when the pH is 7 , the adsorption time is 100 min, temperature is $37^{\circ} \mathrm{C}$, adsorbent mass is $1.2 \mathrm{~g}$. 

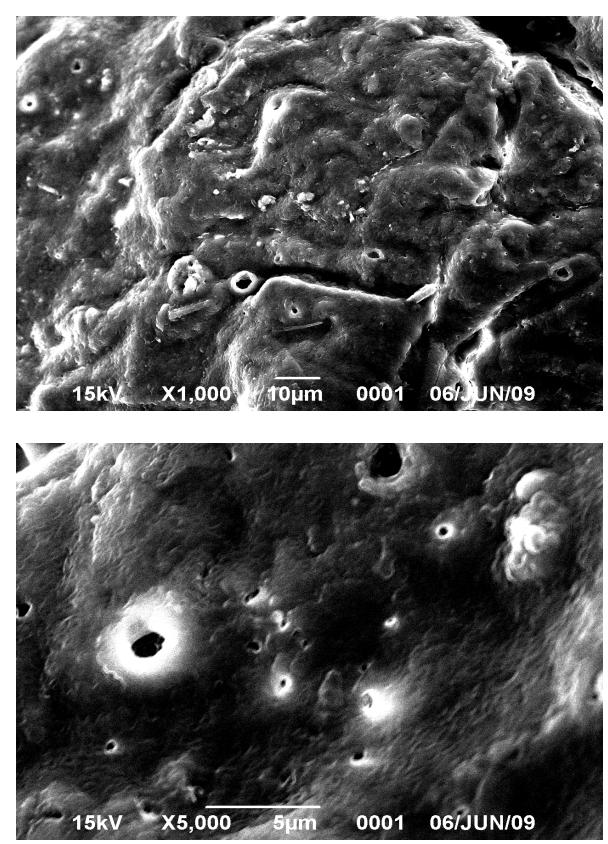

Fig. 1. Electron micrographs of sodium alginate immobilized Bacillus subtilis
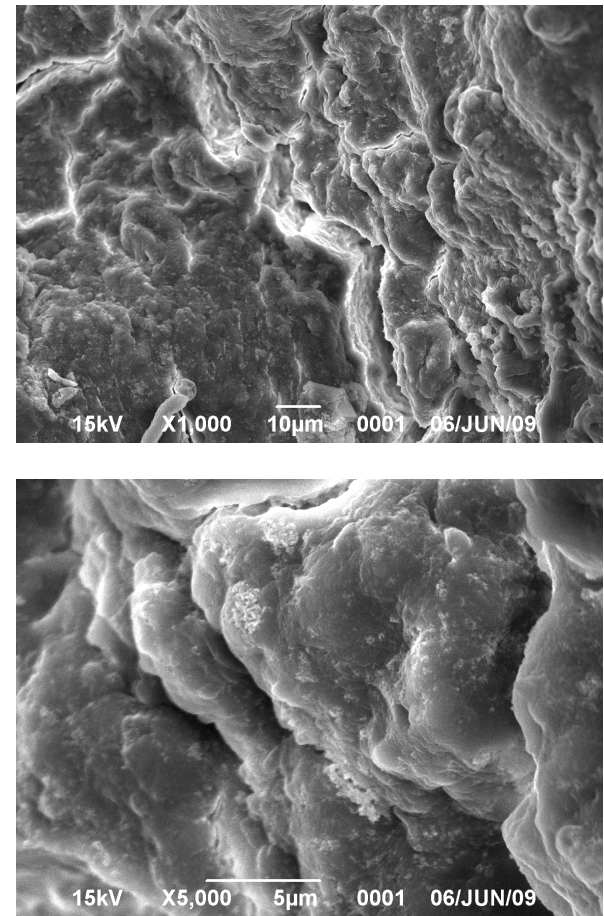

Fig. 2. Electron micrographs of sodium alginate immobilized B. subtilis (live) adsorb $\mathrm{Cr}^{6+}$ among the 4 factors: speed, temperature, $\mathrm{pH}$, adsorbent concentration, $\mathrm{pH}$ has the biggest effect on the adsorption of chromium ion in the mine wastewater, followed by the speed, adsorbent concentration, the temperature has the least effect. As time increased, the adsorption capacity is becoming increasingly large; however, when the adsorption reached saturation, the adsorption capacity will not increase, the curve shows a downward trend; the adsorption efficiency of the small ball adsorb chromium in the mine wastewater affected by the physical and chemical state of solution, among which temperature is a more significant factor. As the adsorption reaction is a chemical process, the adsorption capacity will increase as the temperature rises; $\mathrm{pH}$ value is also a effective factor, in the experiment adsorbent dosage increased as the $\mathrm{pH}$ value decreases, when the $\mathrm{pH}$ is 7 , the adsorption effect is the best; through the study of experiment conditions, the removal rate of $\mathrm{Cr}$ in wastewater can reach $80 \%$, it has a significant removal effect.

\section{REFERENCES}

1. J. Sastre, E. Hernández and R. Rodríguez, X. Alcobé, M. Vidal and G. Rauret, Sci. Total Environ., 329, 261 (2004).

2. J. Aguilar, C. Dorronsoro, E. Fernandez, J. Fernandez, I. Garcia, F. Martin and M. Simon, Environ. Pollut., 132, 395 (2004).

3. J.-M. Zhang, J. Xian United Univ., 2, 6 (2003).

4. L.S. Cai, W.T. Chen and L. Huang, Chem. Ind. Times, 3, 20 (2006).

5. H. Yin, J.-S. Ye, H. Peng, N. Zhang and L.-P. Yu, Environ. Chem., 5, 22 (2003).

6. Y.-S. Chen, Q.-J. Sun and D.-L. Wang, Shanghai Environ. Sci., 7, 17 (1998).

7. H.-B. Zhang, Y. Zheng, F. Zeng, Z.-Y. Zhu and J. Wang, Microbiology, 3, 32 (2005).

8. M. Lqbal and R.G.J. Edyvean, Miner. Eng. Internat., 17, 217 (2004).

9. N.J. Akhtar, J. Iqbal and M. Iqbal, Lett. Appl. Microbiol., 37, 149 (2003)

10. C.-M. Li, H. Han, L. Zhang and X.-S. Chen, J. Anhui Agric. Sci., 7, 34 (2006). 